\title{
Babesiosis and anaplasmosis in dairy cattle in Northeastern Brazil ${ }^{1}$
}

\author{
Francisco de A.L. Souza ${ }^{2 *}$, Juliana F.V. Braga ${ }^{3}$, Lidiany V. Pires ${ }^{2}$, Ciro J.S. de Carvalho ${ }^{2}$, \\ Érica A. Costa ${ }^{3}$, Múcio F.B. Ribeiro ${ }^{4}$, Renato L. Santos ${ }^{3}$ and Silvana M.M.S. Silva ${ }^{5}$
}

\begin{abstract}
Souza F.A.L., Braga J.F.V., Pires L.V., Carvalho C.J.S., Costa E.A., Ribeiro M.F.B., Santos R.L. \& Silva S.M.M.S. 2013. Babesiosis and anaplasmosis in dairy cattle in Northeastern Brazil. Pesquisa Veterinária Brasileira 33(9):1057-1061. Departamento de Clínica e Cirurgia Veterinária, Centro de Ciências Agrárias, Universidade Federal do Piauí, Av. Universitária s/n, Teresina, PI 64049-550, Brazil. E-mail: chicoleite@hotmail.com

The goal of this study was to characterize the epidemiological situation and the factors involved in the prevalence of babesiosis and anaplasmosis in cattle in the dairy basin of Parnaíba, Piauí, Brazil. The study was conducted in 22 farms, and collected blood samples from 202 cattle to study serological, molecular and determination of the packed cell volume (PCV). On the farms were applied surveys involving epidemiological aspects. Seroprevalence rates were: Babesia bigemina 52.5\%, B. bovis 68.8\%, and Anaplasma marginale $89.1 \%$. Of the samples analyzed, $73.3 \%$ were reactive for Babesia spp. and A. marginale, showing co-infection. In PCR, B. bigemina and B. bovis were positive in $52.0 \%$ and $33.2 \%$ respectively, and A. marginale in 76.2\%. Of these, 51.5\% amplified DNA of Babesia spp. and $A$. marginale. The semi-intensive management predominated in $68.0 \%$ of the farms studied. The clinical history of babesiosis and anaplasmosis, was reported from $73 \%$ of the farms. There was no significant difference $(p>0.05)$ between age groups and for the PCV of positive compared with negative animals. The study indicates that in this region is enzootic instability for babesiosis and enzootic stability for anaplasmosis, reinforcing the fact that in Brazil there are areas of enzootic instability, even in tropical regions of the country. The PCR technique was a valuable tool for the diagnosis of these diseases and may be used to characterize a geographic region.
\end{abstract}

INDEX TERMS: Babesia bigemina, Babesia bovis, Anaplasma marginale, epidemiology, diagnostic.

RESUMO.- [Babesiose e anaplasmose em bovinos leiteiros no Nordeste do Brasil.] O objetivo deste estudo foi caracterizar a situação epidemiológica e os fatores envolvidos na prevalência da babesiose e anaplasmose em bovinos da bacia leiteira de Parnaíba, Piauí, Brasil. 0 estudo foi realizado em 22 propriedades, sendo coletadas amostras

\footnotetext{
${ }^{1}$ Received on January 12, 2013.

Accepted for publication on May 28, 2013.

Part of the Master Thesis of the first author

${ }^{2}$ Programa de Pós-Graduação em Ciência Animal, Centro de Ciências Agrárias (CCA), Universidade Federal do Piauí (UFPI), Av. Universitária s/n, Teresina, PI 64049-550, Brazil. *Corresponding author: chicoleite@hotmail.com

${ }^{3}$ Laboratório de Patologia Molecular, Departamento de Clínica e Cirurgia Veterinária, Escola de Veterinária, Universidade Federal de Minas Gerais (UFMG), Av. Antônio Carlos 6627, Belo Horizonte, MG 30123-970, Brazil.

${ }^{4}$ Laboratório de Protozoologia (LPV), Departamento de Parasitologia, Instituto de Ciências Biológicas (ICB), UFMG, Av. Antônio Carlos 6627, Belo Horizonte, MG 30270-901, Brazil.

${ }^{5}$ Departamento de Clínica e Cirurgia Veterinária, CCA-UFPI, Av. Universitária $\mathrm{s} / \mathrm{n}$, Teresina, PI.
}

de sangue de 202 bovinos para estudos sorológicos, moleculares e determinação do volume globular (VG). Nas propriedades foram aplicadas inquéritos envolvendo aspectos epidemiológicos. As taxas de soroprevalência foram: $52,5 \%$ para Babesia bigemina, 68,8\% B. bovis, e 89,1\% para Anaplasma marginale. Das amostras analisadas, $73,3 \%$ foram reagentes para Babesia spp. e A. marginale, demostrando co-infecção. Na PCR, B. bigemina e B. bovis foram positivas em $52,0 \%$ e $33,2 \%$ respectivamente, e $A$. marginale em 76,2\%. Destes, 51,5\% amplificaram DNA de Babesia spp. e A. marginale. 0 manejo semi-intensivo predominou em $68,0 \%$ das propriedades estudadas. O histórico clínico de babesiose e anaplasmose foi relatado em $73 \%$ das propriedades. Não houve diferença significativa $(p>0,05)$ entre as faixas etárias e para o VG de animais positivos comparados com os negativos. 0 estudo indica que nesta região há instabilidade enzoótica para babesiose e estabilidade enzoótica para anaplasmose, reforçando o fato de que, no Brasil, existem áreas de instabilidade enzoótica, mesmo em regi- 
ões tropicais do país. A técnica de PCR demonstrou ser uma ferramenta valiosa para o diagnóstico destas doenças e pode ser utilizada para caracterizar uma região geográfica.

TERMOS DE INDEXAÇÃO: Babesia bigemina, Babesia bovis, Anaplasma marginale, epidemiologia, diagnóstico.

\section{INTRODUCTION}

Bovine babesiosis is caused by the hemoprotozoa Babesia bovis and Babesia bigemina, whereas anaplasmosis is caused by the intra-erythrocytic rickettsia Anaplasma marginale. These diseases are clinically and epidemiologically similar (Bock et al. 2004, Kocan et al. 2010), and they are responsible for significant economic losses for the livestock industry worldwide.

The most important biological vector for these three agents is the tick Rhipicephalus (Boophilus) microplus, whi$\mathrm{ch}$ is distributed in tropical and subtropical regions (Estrada-Peña et al. 2006, OIE 2007). In addition to the biological transmission by ticks, $A$. marginale can be transmitted mechanically by bloodsucking flies or iatrogenically form by fomites contaminated with blood from infected cattle (Dreher et al. 2005, Kocan et al. 2010). The dynamics of infection of these parasites is dependent on factors such as vector population, transmission capability of the vector, and host susceptibility (Kocan et al. 2010).

Direct diagnosis of these diseases is based on detection of the agent in the blood smears (Bock et al. 2004) or by polymerase chain reaction (PCR) or nested PCR (nPCR) (Figueroa et al. 1993, Costa Júnior et al. 2006). Indirect diagnostic methods include serological methods such as enzyme-linked immunosorbent assays (ELISA) (Madruga et al. 2001), and indirect fluorescent antibody test (IFAT) (Santos et al. 2001).

Epidemiological assessment of babesiosis and anaplasmosis in a given area allows to predict the risk for occurrence of outbreaks. Therefore, the epidemiological situation can be classified as three types: enzootic stability, enzootic instability, and disease-free areas (Mahoney 1974). Most of the Brazilian territory is characterized as an area of enzootic stability for Babesia spp. and A. marginale (Barci et al. 1994, Araújo et al. 1997, Madruga et al. 2000, Santos et al. 2001). However, the Southern and Northern parts of Brazil include areas of enzootic instability (Artiles et al. 1995, Lima et al. 1999).

Studies on the epidemiological situation of babesiosis and anaplasmosis in Northeastern Brazil are extremely scarce. Considering that dairy cattle in this region play an significant social and economic role, epidemiological studies are very important in this region, particularly due to the fact that there exist peculiar climatic patterns.

The epidemiological situation of bovine babesiosis and anaplasmosis in Piaui (Northeast Brazil) is not known. Cattle mortality associated with clinical signs of these diseases have reported, but without laboratory confirmation. The goal of this study was to determine the prevalence of babesiosis and anaplasmosis in cattle in the dairy basin of Parnaíba, State of Piauí, with parasitological, serological, and molecular methods, in association with possible risk factors involved.

\section{MATERIALS AND METHODS}

Study area. This study was conducted in the dairy basin of Parnaíba, in the micro-region Litoral Piauiense, in the Northern part of the State of Piaui, Northeast Brazil. This area is located between longitudes $41^{\circ} 39^{\prime} \mathrm{W}$ e $42^{\circ} 05^{\prime} \mathrm{W}$ and latitudes $2^{\circ} 51^{\prime} \mathrm{S}$ e $3^{\circ} 55^{\prime} \mathrm{S}$ (Fig.1). This micro-region covers an area of $7,742 \mathrm{~km}^{2}$, with a herd of 99,815 cattle (IBGE, 2010). The climate is classified as tropical with two well-defined seasons: the rainy season from December to April and the dry season from May to November. Temperature ranges from 23 to $33.6^{\circ} \mathrm{C}$, with $40-80 \%$ relative air humidity, and an average rainfall of 1,200mm (Medeiros 2004).

Blood samples. Twenty two dairy farms were sampled. These farms have been randomly selected from the ADAPI (Agência de Defesa Agropecuária do Piauí) files, restricting the selection to farms that had no regular veterinary assistance and reasonably easy accessibility. Questionnaires regarding several epidemiological aspects such as type of breeding, sanitary conditions, clinical signs of diseases and control measures were applied to all herds. Samples were collected from all municipalities that are part of that particular dairy basin, proportionally to their cattle population. In total, 202 cattle over the age of one year were sampled. The sample size was determined based on a mathematical model developed by the Centro Pan Americano de Zoonosis (1979). An estimated prevalence of $67 \%$ was considered for calculation of the number of cattle to be sampled. This estimated prevalence

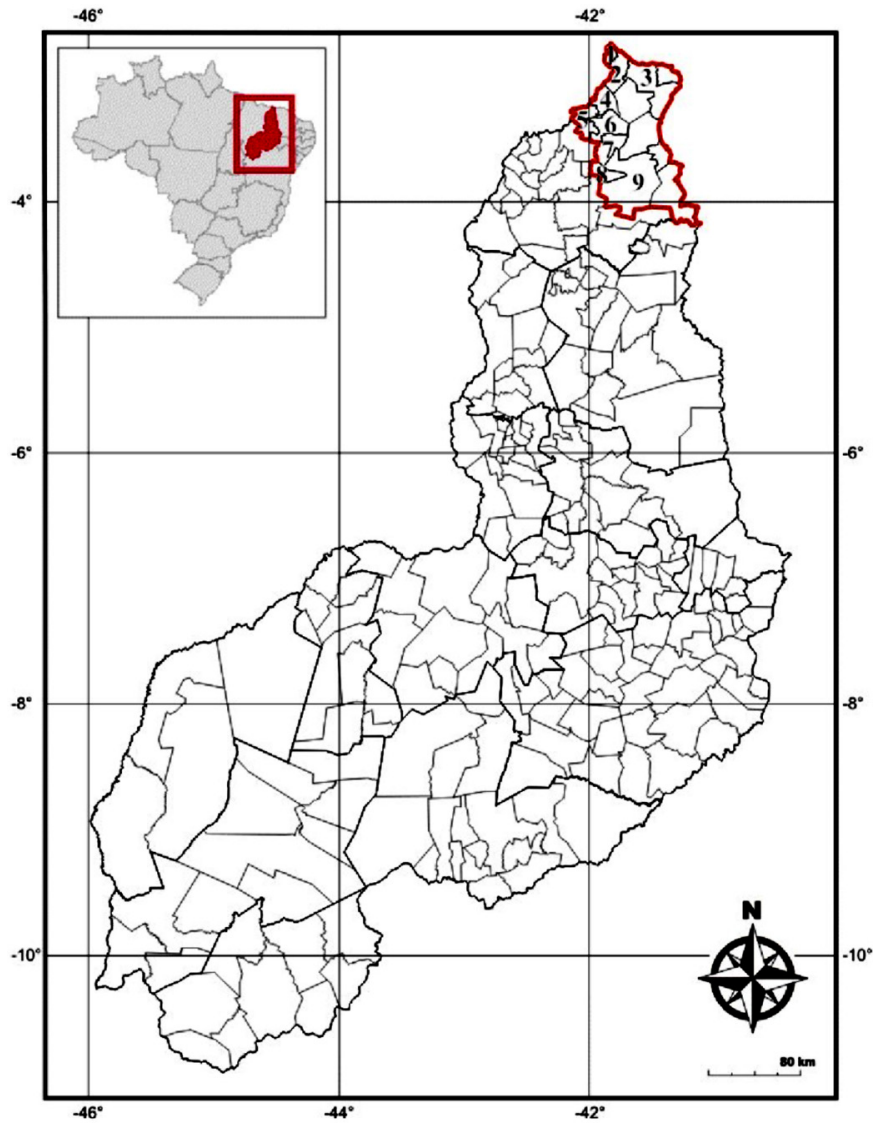

Fig.1. Map showing the location of Piauí micro-region Litoral Piauiense and municipalities that make up the dairy basin of Parnaíba, which had undertaken the study of babesiosis and bovine anaplasmosis: (1) Ilha Grande, (2) Parnaíba, (3) Luis Correia, (4) Buriti dos Lopes, (5) Murici dos Portelas, (6) Caxingó, (7) Caraúbas do Piauí, (8), São José do Divino, and (9) Piracuruca. 
Table 1. Packed cell volume (PCV) and prevalence of Babesia bigemina, Babesia bovis and Anaplasma marginale by serological or molecular diagnostic methods applied to cattle from the dairy basin of Parnaíba, Piauí, Brazil, 2010

\begin{tabular}{|c|c|c|c|c|}
\hline & B. bigemina & B. bovis & A. marginale & $\begin{array}{c}\text { Co-infection (Babesia spp. } \\
\text { and } A \text {. marginale) }\end{array}$ \\
\hline Seroprevalence (IFA) & $52.5 \%(106 / 202)$ & $68.8 \%(139 / 202)$ & $89.1 \%(180 / 202)$ & $73.3 \%(148 / 202)$ \\
\hline Seropositive & $29.38 \pm 5 ; 03^{a}$ & $29.27 \pm 5.19^{a}$ & $29.07 \pm 4.96^{\mathrm{a}}$ & $29.17 \pm 4.91^{\mathrm{a}}$ \\
\hline Seronegative & $28.84 \pm 4.90^{\mathrm{a}}$ & $28.76 \pm 4.41^{\mathrm{a}}$ & $29.48 \pm 5.07^{a}$ & $27.20 \pm 7.25^{\mathrm{a}}$ \\
\hline
\end{tabular}

${ }^{a}$ Means in the same column followed by same letter do not differ ( $\left.p>0.05\right)$ by Student's $t$ test.

was based on a preliminary experiment that included 78 cattle of this area, considering a degree of confidence of $95 \%$, with an accepted $10 \%$ margin of error.

Blood samples with anticoagulant (EDTA) were used to determine the packed cell volume (PCV) by the microhematocrit technique, and for DNA extraction. Serum samples were obtained for IFAT.

Serology. Anti-Babesia bigemina, anti-B. bovis and anti-Anaplasma marginale IgG was detected by IFAT according to the Instituto Interamericano de Cooperación para la Agricultura (IICA 1987). Samples that were reactive at a dilution $\geq 1: 40$ were considered positive.

DNA extraction, PCR, nPCR and sequencing. DNA was extracted from blood samples using a commercial kit (Illustra ${ }^{\text {m }}$ blood genomicPrep Mini Spin - GE Healthcare) following the manufacturer's instructions. PCR was used for amplification of DNA from B. bovis and B. bigemina, using previously described primers: GAU9/GAU10 and GAU7/GAU6 respectively (Linhares et al. 2002). Amplification of $A$. marginale was performed by nPCR using the primers Am9 and Am10, followed by an internal amplification with the primers Am11 and Am12 (Figueroa et al. 1993). PCR and nPCR were performed in a $25 \mu \mathrm{l}$ reaction, containing ultra-pure water; $1 \mathrm{x}$ Taq buffer; $0.2 \mathrm{mM}$ each dNTP (Promega); $1.0 \mathrm{mM} \mathrm{MgCl}_{2} ; 0.4 \mu \mathrm{M}$ each primer; $1.5 \mathrm{U}$ Taq DNA polimerase (Promega) and $200 \mathrm{ng}$ of sample DNA. The second round of amplification in the case of nPCR was performed with a $1 \mu$ l of a previously amplified PCR product. Reactions were performed under the following conditions: $94^{\circ} \mathrm{C}$ for $2 \mathrm{~min}$ (B. bovis and B. bigemina) or $95^{\circ} \mathrm{C}$ for $7 \mathrm{~min}$ (A. marginale); 35 cycles of denaturation for $30 \mathrm{~s}$ at $94^{\circ} \mathrm{C}(B$. bovis and B. bigemina) or 95으 (A. marginale); annealing for $30 \mathrm{~s}$ at $58^{\circ} \mathrm{C}$ (B. bovis) or $60^{\circ} \mathrm{C}$ (B. bigemina and A. marginale); extension for $1 \mathrm{~min}$ at $72^{\circ} \mathrm{C}$, and a final extension at $72^{\circ} \mathrm{C}$ for $5 \mathrm{~min}$ in a Gene Pro thermocycler (Bioer).

Amplified products were subjected to electrophoresis in 1.5\% agarose gel. PCR products had 541 bp for B. bovis, 690 bp for $B$. bigemina, and $170 \mathrm{bp}$ for $A$. marginale.

Sequencing of PCR products amplified (B. bovis, B. bigemina, and $A$. marginale) from cattle blood samples were carried out in both directions using the ABI Prism BigDye Terminator Cycle Sequencing Ready Reaction Kit (Applied Biosystems). About 10ng of purified DNA, for each sequencing reaction, was combined with $3.2 \mathrm{pmol}$ of primer (forward and/or reverse) used in the amplification reaction. Nucleic acid sequence analyses were performed on an automated ABI PRISM 3500 Genetic Analyzer DNA sequencer.

Consensus sequences were obtained through the analysis of the sense and antisense sequences using the GAP version 1.4 Staden Package (http://staden.sourceforge.net/). Comparisons were made with the sequences deposited in GenBank using the Basic Local Alignment Search Tool - BLAST (http://www.ncbi. nlm.nih.gov/BLAST/).
Statistical analysis. All statistical analyses were performed using a commercial statistical package GraphPad Prism, version 5.0. Data analysis was performed using Chi-square test, with a significance level of 0.05 . The mean and standard deviations were estimated for PCV values. Mean PCV values of infected (as assessed by PCR) and seropositive cattle were compared with those of the uninfected and seronegative cattle using Student's t-tests. Prevalence was estimated based on the total number of IFAT-positive cattle and total infected by PCR.

Ethics and animal experimentation. This study was conducted under the terms and conditions of the Ethics Committee for Animal Experimentation of the Universidade Federal do Piauí, approved under number 030/2010.

\section{RESULTS}

Prevalence of Babesia bigemina, B. bovis, and Anaplasma marginale as determined by IFAT and by PCR amplification of DNA, ranged from $33.2 \%$ to $89.1 \%$ depending on the species and method used for detection (Table 1). As shown in Figure 2, there was no statistically significant differences $(\mathrm{p}>0.05)$ in the prevalence of $B$. bovis, B. bigemina, and $A$. marginale, when various age groups were compared.

PCV ranged from $14 \%$ to $42 \%$, by mean PCV of cattle positive for B. bigemina, B. bovis, A. marginale as well as co-infected cattle as demonstrated by PCR were not significantly different $(\mathrm{p}>0.05)$ from negative cattle (Table 1$)$.

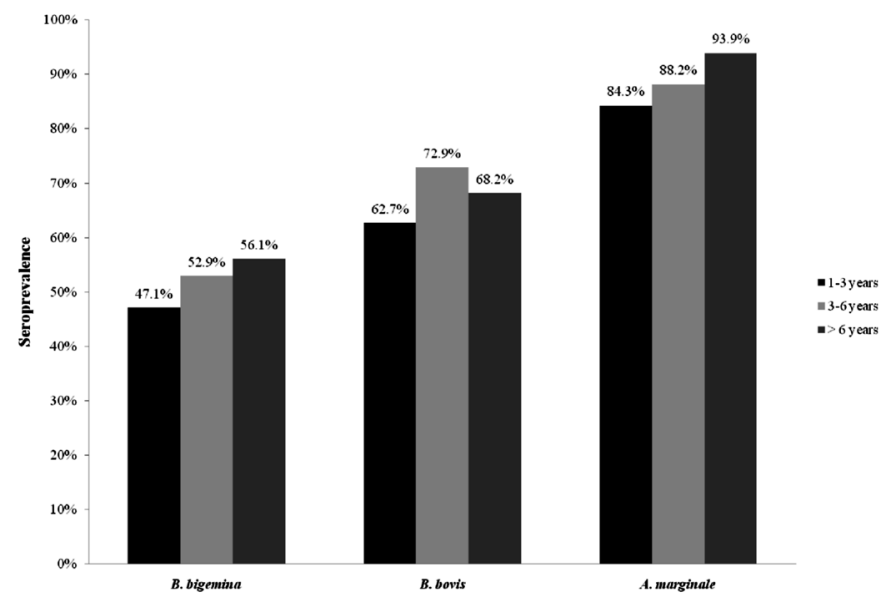

Fig.2. Seroprevalence of Babesia bigemina, Babesia bovis and Anaplasma marginale antibodies by age group in cattle from the dairy basin of Parnaíba, state of Piauí, Northeastern Brazil. No significant difference ( $p>0.05$ ) between age groups, according Chi-square test. 
Amplification and sequencing of a $681 \mathrm{bp}$ fragment of the 18S rRNA gene of B. bigemina (deposited in GenBank under accession number JX104106) demonstrated 99\% identity to sequences of B. bigemina from cattle in Spain (DQ785311 and FJ426361), Germany (EF458190), and China (AY603402); B. bigemina from water buffalo in China (HQ840960), and from white-tailed deer in the USA (HQ264115). Similar results were observed with B. bovis 18S rRNA gene sequences generated in this study (accession number JX661267), a 543 bp fragment that had 100\% identity with $B$. bovis from cattle in the USA (L31922), and 99\% identity from cattle in Germany (EF458218), and from white-tailed deer in USA (HQ264126). A $161 \mathrm{bp}$ amplified fragment of the major surface protein gene of $A$. marginale had $98 \%$ identity to sequences of complete genome $A$. marginale Florida strain from cattle in USA (CP001079) and the Maries strain (CP000030).

A semi-intensive management was practiced in $68 \% \mathrm{t}$ of the 22 farms included in this study. Cattle in these farms were predominantly crossbreed of Gir (Bos taurus indicus) with Holstein (Bos taurus taurus). Most farms (95\%) had cultivated pastures, but only $59 \%$ of them adopted pasture rotation. All farms had cattle infested with ticks at the time of interview, whereas $64 \%$ also reported the presence of hematophagous diptera. All farms adopted procedures for controlling the population of ticks, based on acaricide treatments, but these procedures were perfomed without veterinarian supervision or a strategic control plan. Clinical history and/or signs of babesiosis and/or anaplasmosis including anorexia, apathy, pale mucous membranes, hemoglobinuria, fever, icteric mucous membranes, and abortion were reported in $73 \%$ of the farms, and only $68 \%$ of the farms treated cattle for these diseases. In $50 \%$ of the farms were reported deaths associated with clinical history of the disease. Most of the farms (95\%) kept calves up to six months of age within a collective hutch with food and water. These calves had contact with cows only during milking, but even at this stage calves were already infested with ticks.

\section{DISCUSSION}

Low seroprevalence rate of Babesia bigemina and B. bovis observed in this study allow us to consider this region as an area of enzootic instability. In the case of Anaplasma marginale, due to high seroprevalence, this same region is characterized by an area of enzootic stability. This classification is based on epidemiological concepts proposed by Mahoney (1974) that describes its application to control possible outbreaks.

Seroprevalence rates for B. bigemina and B. bovis demonstrated in this study were lower than the seroprevalences previously reported in most states in the Northeast region of Brazil, where predominates areas of enzootic stability. In a study conducted in semi-arid region of Bahia, the prevalence of antibodies anti-B. bigemina and anti-B. bovis was $77.7 \%$ and $75.5 \%$, respectively (Barros et al. 2005). In the micro-regions of Feira de Santana, Jequié, Ilhéus, and Vitória da Conquista (Bahia State), the average percentages of cattle serologically positive for B. bovis and B. bigemina were $97.2 \%$ and $95.0 \%$, respectively (Araújo et al. 1997). In the region known as Araguaína (Tocantins State) seroprevalence determined for B. bovis was $90.5 \%$ (Trindade et al. 2010). The unstable situation found in this study may high risk of clinical manifestation of infections in this region because there is the possibility of outbreaks of babesiosis in adult animals causing high mortality rate and economic losses. For A. marginale the result seroprevalence found resembles the one recorded for other regions of Brazil (Souza et al. 2000, Souza et al. 2001), but differs in some Northeastern states, such as Sergipe, where a prevalence of $16.3 \%$ has been reported (Oliveira et al. 1992).

Regarding that age, seroprevalences of B. bovis, B. bigemina, and $A$. marginale did not differ statistically among groups, suggesting that these animals are infected mostly before they reach one year of age, when they tend to be more resistant to hemoparasites. Incidence of these diseases is highly variable among adult cattle as previously reported by Souza et al. (2000), Trindade et al. (2010), and Barros et al. (2005).

The frequency of infection with Babesia spp. and A. marginale in cattle as determined by PCR and nPCR was similar to frequencies obtained by IFA serological test. These molecular methods allow detection of babesiosis and anaplasmosis during the initial phase of infection as well as asymptomatic carriers, and therefore they are powerful tools for epidemiological investigations, once these animals represent a major source of infection for female $R$. (B.) $\mathrm{mi}$ croplus (Oliveira-Sequeira et al. 2005). PCR and nPCR methods employed in this study have been previously used for research of these diseases in several Brazilian states (Figueroa et al. 1993, Madruga et al. 2002, Oliveira-Sequeira et al. 2005, Costa Júnior et al. 2006). This demonstrated that the Parnaíba dairy basin is an area of enzootic stability for A. marginale and instability for B. bigemina and B. bovis. In the geographic area of this study, semi-intensive farms are predominantly associated with high temperatures and low rainfall (close to zero during the dry season), what is likely to interfere with the life cycle of the tick, thus influencing the risk of infection with Babesia spp. This notion is in good agreement with a previous report by Ouhelli et al. (1987), who found that at high temperatures ( 25 to $35^{\circ} \mathrm{C}$ ) there is a reduction in oviposition, hatching rate, and longevity of the larvae infected by B. bigemina and B. bovis; this results in a decreased risk of transmission of Babesia spp., favoring enzootic instability, whereas enzootic stability in the case of Anaplasma may be due to a mechanical transmission.

As shown in this study, based on answers to the questionnaires, ticks and hematophagous flies were present in most of the farms. Improvement in health management, such as intensive use of insecticides and acaricides reduced the exposure of cattle to vectors of babesiosis and anaplasmosis, resulting in low infectious challenge for calves. This situation favors the emergence of areas of endemic instability (Guglielmone 1995, Bock et al. 2004). No characteristic clinical signs of babesiosis and/or anaplasmosis were observed while visiting the farms included in this study, what may be a consequence of widespread treatment of affected cattle adopted by farmers in this region (Kuttler \& Johnson 1996, Kocan et al. 2010). 
Our results indicated that cattle PCR and serologically positive for babesiosis and anaplasmosis had PCV values that were similar to negative cattle, and that anemia was occasionally observed in a few individual animals. Considering that anemia is proportional to parasitemia due to disseminated intravascular hemolysis as well as mechanisms sequestration and lysis of normal erythrocytes (Alfonso et al. 1996), it is likely that the levels of parasitaemia observed in this study were below the threshold required for triggering clinical disease.

\section{CONCLUSION}

Our results indicate that Babedsia bigemina, B. bovis, and Anaplasma marginale infections occur in the dairy basin of Parnaíba in the state of Piaui, with features of enzootic instability in the case of babesiosis, and enzootic stability in the case of anaplasmosis.

Acknowledgements.- To Dr. Eduardo Esmeraldo Beserra for helping in the samples collection of field level. F.A.L. Souza had a schoolarship from FAPEPI (Fundação de Amparo à Pesquisa do Estado do Piauí). Work in R.L. Santos' laboratory was supported by CAPES (Coordenação de Aperfeiçoamento de Pessoal de Nível Superior) and CNPq (Conselho Nacional de Desenvolvimento Científico e Tecnológico).

\section{REFERENCES}

Alfonso J., Medina R., Fazzino F. \& Caballero H. 1996. Câmbios clinicos y hematológicos em becerros infectados com Anaplasma marginale. Acta Cientifica Venezolana 47:50-57.

Araújo F.R., Madruga C.R., Almeida M.A.O., Leal C.R.B. \& Miguita M. 1997. Levantamento sorológico de Babesia bovis e Babesia bigemina no Estado da Bahia pela imunofluorescência indireta e teste de conglutinação rápida. Revta Brasil. Parasitol. Vet. 6:111-115.

Artiles J., Alves Branco F.P., Martins J.R., Correa L.B. \& Sapper M.F.M. 1995. Prevalência de Babesia bovis, Babesia bigemina e Anaplasma marginale no município de Bagé, RS. Revta Bras. Parasitol. Vet. 4:187.

Barci L.A.G., Oliveira M.R., Machado R.Z., Oliveira D.A. \& Araújo Filho R.S. 1994. Epidemiologia da babesiose bovina no Estado de São Paulo. I. Estudo em rebanhos produtores de leite tipo B do município de Pindamonhagaba, Vale do Paraíba. Revta Bras. Parasitol. Vet. 3:79-82.

Barros S.L., Madruga C.R., Araújo F.R., Menk C.F., Almeida M.A.O., Melo E.P.S. \& Kessler R.H. 2005. Serological survey of Babesia bovis, Babesia bigemina, and Anaplasma marginale antibodies in cattle from the semi-arid region of the state of Bahia, Brazil, by enzyme-linked immunosorbent assays. Mem. Inst. Oswaldo Cruz 100:613-617.

Bock R., Jackson L., De Vos A. \& Jorgensen W. 2004. Babesiosis of cattle. Parasitology 129:247-269.

Centro Pan Americano de Zoonosis 1979. Procedimientos para estudios de prevalência por muestreo. Nota Técnica 18, Ramos Mejia, Buenos Aires. 35p.

Costa Júnior L.M., Rabelo E.M.L., Martins Filho O.A. \& Ribeiro M.F.B. 2006. Comparison of different direct diagnostic methods to identify Babesia bovis and Babesia bigemina in animals vaccinated with live attenuated parasites. Vet. Parasitol. 139:231-236.

Dreher U.M., Hofmann-Lehmann R., Meli M.L., Regula G., Cagienard A.Y., Stark K.D.C., Doherr M.G., Filli F., Hassig M., Braun U., Kocan K.M. \& Lutz H. 2005. Seroprevalence of anaplasmoses among cattle in Switzerland in 1998 and 2003: No evidence of an emerging disease. Vet. Microbiol. 107:71-79.

Estrada-Peña A., Bouattour A., Camicas J.L., Guglielmone A., Horak I., Jongejan F., Latif A., Pegram R. \& Walker A.R. 2006. The known distribution and ecological preferences of the tick subgenus Boophilus (Acari: Ixodidae) in Africa and Latin America. Exp. Appl. Acarology 38:219-235.

Figueroa J.V., Chieves L.P., Jhonson G.S. \& Buenning G.M. 1993. Multiplex polymerase chain reaction based assay for the detection of Babesia bigemina, B. bovis and Anaplasma marginale DNA in bovine blood. Vet. Parasitol. 50:69-81.

Guglielmone A.A. 1995. Epidemiology of babesiosis and anaplasmosis in South and Central America. Vet. Parasitol. 57:109-119.

IBGE 2010. Produção da pecuária municipal 2009. Instituto Brasileiro de Geografia e Estatística. <http://www.sidra.ibge.gov.br/bda/tabela/listabl.asp?c=73\&z=p\&o=21>

IICA 1987. Técnicas para el Diagnóstico de Babesiosis y Anaplasmosis Bovina. Instituto Interamericano de Cooperación para la Agricultura, San José. 79p.

Kocan K.M., De La Fuente J., Blouin E.F., Coetzee J.F. \& Ewing S.A. 2010. The natural history of Anaplasma marginale. Vet. Parasitol. 167:95-107.

Kuttler K.L. \& Johnson L.W. 1996. Chemoprophilactic activity of imidocarb, diaminazene and oxytetracycline against Babesia bovis and Babesia bigemina. Vet. Parasitol. 21:107-118.

Lima F.V.A., Molnar E., Molnar L., Silva C.M.S. \& Lima F.V.A. 1999. Seroepidemiological study of bovine babesiosis (Babesia bovis) by indirect ELISA test in the State of Para, Brazil. Revta Ciênc. Agrárias 32:55-64.

Linhares G.F.C., Santana A.P., Laueman L.H. \& Madruga C.R. 2002. Assessment of primers designed from the small ribosomal subunit RNA for specific discrimination between Babesia bigemina and Babesia bovis by PCR. Ciênc. Anim. Bras. 3:27-32.

Madruga C.R., Leal C.R.B., Ferreira A.M.T., Araújo F.R., Bonato L.V., Kesler R.H., Schenk M.A.M. \& Soares C.O. 2002 Genetic and antigenic analysis of Babesia bigemina isolates from five geographical regions of Brazil. Pesq. Vet. Bras. 22:153-160.

Madruga C.R., Marques A.P.C., Araújo F.R., Umaki A.C.S., Crocci A.J. \& Queiroz R. A. 2001. Avaliação de um ELISA para detecção de anticorpos contra Babesia bigemina em bovinos e sua aplicação em um inquérito sorológico no Brasil. Pesq. Vet. Bras. 21:72-76.

Madruga C.R., Marques A.P.C., Carvalho C.M.E., Cusinato F.Q., Crocci A.J., Kessler R.H. \& Miguita M. 2000. Desenvolvimento de uma prova de imunoadsorção enzimática para detecção de anticorpos contra Babesia bovis. Pesq. Vet. Bras. 20:167-170.

Mahoney D.F. 1974. The application of epizootiological principles in the control of babesiosis in cattle. Bull. Off. Int. Epizoot. 81:123-138.

Medeiros R.M. 2004. Estudo Agrometeorológico para o Estado do Piauí. Secretaria do Meio Ambiente e Recursos Hídricos do Estado do Piauí, Teresina. 113p.

OIE. Rhipicephalus (Boophilus) microplus. <http://www.cfsph.iastate.edu/ Factsheets/pdfs/boophilus_microplus.pdf>

Oliveira A.A., Pedreira P.A.S. \& Almeida M.F.R.S. 1992. Doenças de bezerros. II. Epidemiologia da anaplasmose no estado de Sergipe. Arq. Bras. Med. Zootec. 44:377-386.

Oliveira-Sequeira T.C.G., Oliveira M.C.S., Araújo Júnior J.P. \& Amarante A.F.T. 2005. PCR-based detection of Babesia bovis and Babesia bigemina in their host Boophilus microplus and cattle. Int. J. Parasitol. 35:105-111.

Ouhelli H., Pandey V.S. \& Aboughal A. 1987. Effect of infection by Babesia spp. on the development and survival of free-living stages of Boophilus annulatus. Vet. Parasitol. 23:147-154.

Santos H.Q., Linhares G.F.C. \& Madruga C.R. 2001. Estudo da prevalência de anticorpos anti-Babesia bovis e anti-Babesia bigemina em bovinos de leite da microrregião de Goiânia determinada pelos testes de imunofluorescência indireta e Elisa. Ciênc. Anim. Bras. 2:133-137.

Souza J.C.P., Soares C.O., Madruga C.R. \& Massard C.L. 2001. Prevalência de anticorpos anti Anaplasma marginale (Rickettsiales: Anaplasmataceae) em bovinos na mesorregião do Médio Paraíba. Ciênc. Vet. Bra. 31:309314.

Souza J.C.P., Soares C.O., Massard C.L., Scofield A. \& Fonseca A.H. 2000. Soroprevalência de Anaplasma marginale em bovinos na mesorregião Norte Fluminense. Pesq. Vet. Bras. 20:97-101.

Trindade H.I., Silva G.R.A., Teixeira M.C.A., Sousa M.G., Machado R.Z., Freitas F.L.C. \& Almeida K.S. 2010. Detection of antibodies against Babesia bovis and Babesia bigemina in calves from the region of Araguaína, State of Tocantins, Brazil. Revta Bras. Parasitol. Vet. 19:169-173. 